\title{
On the interpretation of decay-associated fluorescence spectra in proteins
}

\author{
A. S. Ladokhin \\ Institute of Molecular Biology and Genetics, National Academy of Sciences of Ukraine \\ 150 Academician Zabolotnoho vul., Kyiv, 031 43, Ukraine \\ Department of Physiology and Biophysics University of California \\ Irvine, CA 92697-4560 U.S.A. \\ E. mail: Jadokhin@uci.edu
}

Calculating decay-associated spectra (DAS) is a common mode of analyzing complex fluorescence decay in proteins. Unfortunately, these spectra are attributed almost exclusively to certain species in the population of macromolecules (rotamers), often without sufficient evidence. An alternative explanation of decay heterogeneity, based on structural relaxation, was believed to require a negative DAS component. Here we demonstrate that dipolar relaxation of the indole molecule, lacking any rotameric forms, doesn't always result in negative pre-exponential amplitude. We conclude that the shape of DAS alone is not sufficient to differentiate among various causes of heterogeneity of tryptophan fluorescence decay in proteins.

"It is very difficult to find a black cat in a dark room ... Especialy if it's not there."

Attributed to Confucius

Tryptophan fluorescence in proteins is known to exhibit a complex decay, which nevertheless can be fitted to a sum of exponentials: $I(t)=\sum \alpha_{i} \exp \left(-t / \tau_{i}\right)$. The origin of the decay heterogeneity has been the subject of multiple studies as well as the recent e-mail discussion summarized by Dr. Callis at the meeting of the Biological Fluorescence subgroup of the Biophysical Society [1]. The two main interpretations are the excitation-state relaxation hypothesis (reviewed in $[2,3])$ and the rotamer hypothesis [4-6]. The latter provides a rationale for global analysis of multiple kinetics [7]. Normally, fluorescence lifetimes, $\tau_{i}$, are designated to be global (i. e. shared between the data sets), while pre-exponential amplitudes, $\alpha_{i}$, are designated non-global. In this way, the global analysis can be used to recover the spectral distribution of $\alpha_{i}$ (the so-called decay-associated spectra or DAS). However, from the very start, the authors of the Global

(C) A. S. LADOKHIN, 2001 approach clearly stated the complexity of interpreting DAS when excited-state reactions are involved, and stressed the necessity of distinguishing DAS from species-associated spectra (SAS) [8, 9]. Unfortunately, in the vast majority of the studies of tryptophan fluorescence in proteins in which DAS are recovered, the latter are attributed exclusively to certain species in the population of macromolecules (rotamers).

Numerous studies indicate that chemical heterogeneity $[10]$ and dipolar relaxation $[11,12]$ in indole's environment lead to complex fluorescence decay. Obviously, indole is deprived of any rotameric forms which simplifies the interpretation. The main argument used against the relaxation hypothesis for protein fluorescence decay heterogeneity was the absence of the negative pre-exponential component on the red wing of emission $[1]$, thought to be a necessary hallmark of the relaxation. Indeed, this feature, reported for indole in glycerol rich $(90 \%$ or more) solutions $[11,12]$, is seldom seen in proteins. However the DAS that exhibits a negative component 

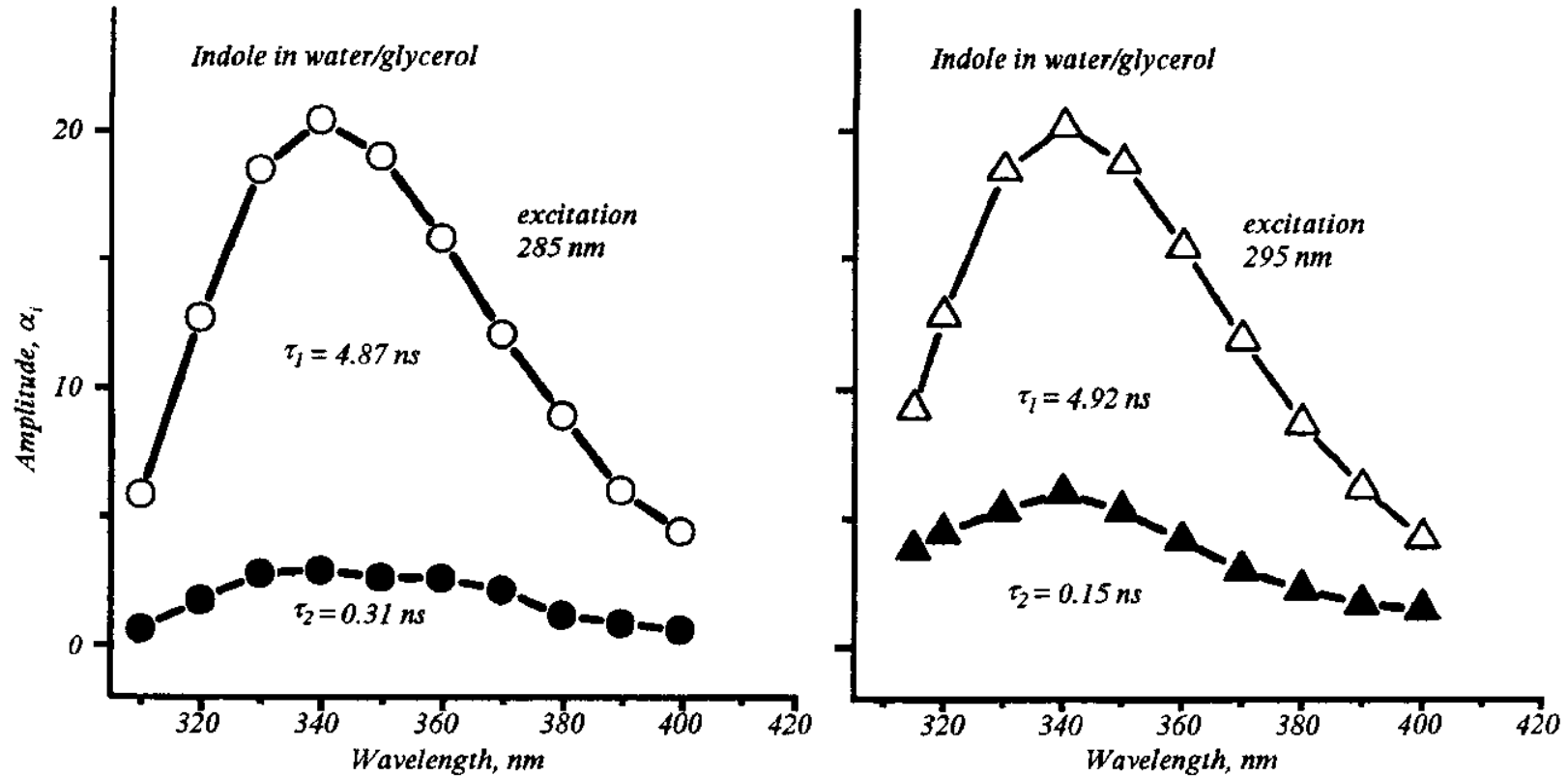

Fig 1. DAS of indole in $40 \%$ glycerol at $10^{\circ} \mathrm{C}$ at two excitations indicated on the graph. Two components (symbols) represent a heterogeneity of decay caused by dipolar relaxation. Red-edge excitation (right-hand panel) results in photo-selection of solvates which are closer to equilibrium in the excited state, resulting in shorter second lifetime
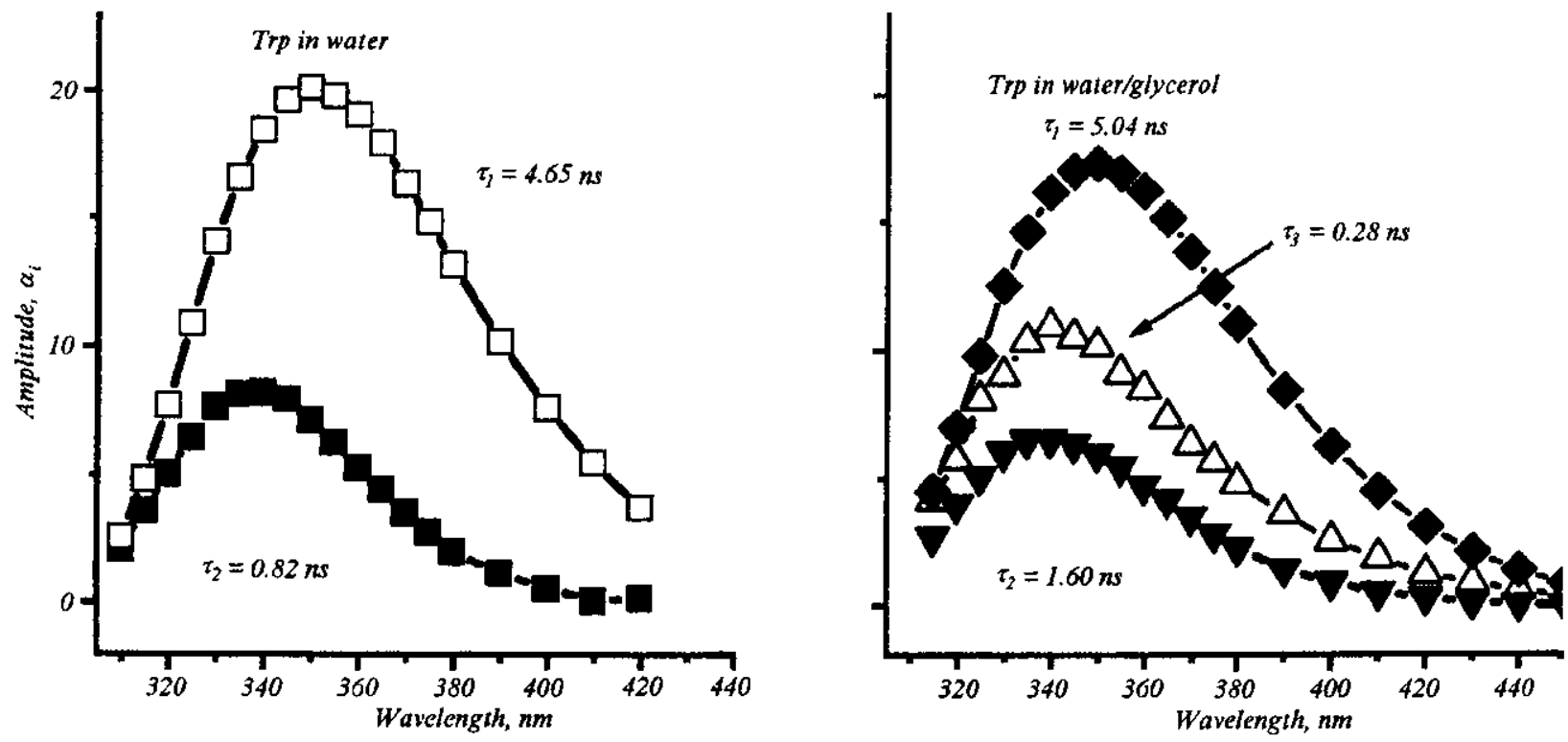

Fig 2. DAS of tryptophan zwitterion in water and in $40 \%$ glycerol at $10{ }^{\circ} \mathrm{C}$ measured with the $295 \mathrm{~nm}$ excitation. Two components (symbols) in the case of tryptophan in water (left-hand panel) are related to rotameric forms. The three components (symbols) observed in $40 \%$ glycerol (right-hand panel) are similar to those observed with many different proteins. There is no possibility to determine from the appearance of the spectra which of them are related to the excited state relaxation and which to the ground state heterogeneity 
in model solutions corresponds to the shortest of three lifetimes and might not always be observed. We had suggested that the existence of DAS with negative amplitude is a sufficient but not necessary indication of excited state reactions [11]. Here we examine this issue in more detail, using water/glycerol mixtures with lower glycerol content ( $3 / 2$ volume units), referred to below as $40 \%$ glycerol. All other experimental details and procedures for calculating DAS were exactly the same as those used in the previous study [11]. Global $\chi^{2}$ for fits presented here were 1.1 or less.

The DAS for indole in $40 \%$ glycerol collected at $10^{\circ} \mathrm{C}$ using two different excitation wavelength are presented in Fig. 1. For this mildly viscous solution only two decay components are required to fit the data and no negative preexponential is observed. Note that the decay time of a minor component decreases under conditions of red-edge excitation (right panel). This change is not consistent with the two-state relaxation in solvate (defined as a chromophore and its solvent shell). Instead, a continuous relaxation in the ensemble of sub-states should be considered. This type of relaxation is well documented for organic dyes in viscous isotropic media and when bound to lipid vesicles (reviewed in [13]). In all cases listed above, non-exponential behavior of fluorescence decay could be explained using a concept of inhomogeneous broadening of electronic spectra of single molecular species. There is no reason why the same concept should not be applied to an indole chromophore in a complex and heterogeneous environment inside the protein.

The DAS for tryptophan zwitterion in water and in $40 \%$ glycerol is presented in Fig. 2. Two components observed in water (left-hand panel) are related to rotameric forms [4]. Addition of the relaxation expected for the mixture (right-hand panel) complicates the picture. While the longest lifetime appears unchanged, the second one increases by a factor of two. and the third subnanosecond component appears. It is likely that the latter is the product of relaxation (compare to the shortest lifetime on Fig. 1), however it might be not the only one. Overall the three DAS obtained for this model system are very typical for those measured with real proteins. Thus, even in the absence of negative preexponential, the DAS for protein could still be influenced by the relaxation phenomena. Indiscriminate application of the global analysis and one-sided interpretation of the results can lead to the over interpretation of fluorescence data. For tryptophan fluorescence we recommend two recent studies $[11,14]$ that suggest the experimental criteria for choosing among various interpretations. One should be careful to chose the physically relevant model for doing global analysis, otherwise one risks ending up chasing a black cat in a dark room.

Acknowledgement: Supported by W. Keck Foundation and GM-46823 from the NIH.

\section{o. С. Ладохін}

До тлумачення спектрів, асоційованих із затуханням флюоресценцін в білках

\section{Резюме}

Обрахунок спектрів, асоційованих із затуханням (САЗ), є звичайним шляхом аналізу складного затухання флюоресчениї в білках. На жаль, ці спектри майже виключно відносять до певних видів у популяцї молекул (ротамерів), часто без достатніх на те підстав. Вважалося, що альтернативне пояснення гетерогенності затухання, пов'язане зі структурнок релаксацісю, потребує неzативної компоненти САЗ. У цій роботі ми демонструсмо, шо дипольна релаксація молекули індолу, позбавленої будь-яких ротамерних форм, не завжди призводить до неzативних при-експоненціальних амплітуд. Ми робимо висновок стосовно того, ио форма САЗ сама по соб не є достатньою, щоб вирізнити серед іниих причну гетерогенності затухання триптофанової флюоресценцї в білках.

\section{A. С. Ладохин}

К интерпретации спектров, ассоциированньг с затуханием флюоресценции в белках

\section{Резюме}

Расчет спектров, ассоциированных с затуханием (САЗ), является обычным путем анализа сложного затухания флюоресценции в белках. К сожалению, эти спектры почти исключительно относят $к$ определенным видам в популяции молекул (ротамеров), иасто без достаточных оснований. Сииталось, что альтернативное объяснение гетерогенности затухания, связанное со структурной релаксацией, требует отрицательной компоненты САЗ. В данной работе мы демонстрируем. что дипольная релаксация молекулы индола, лишенной каких либо ротамерных форм, не всегда приводит к отрицательным при-экспоненциальным амплитудам. Мы делаем вьвод о том, что форма САЗ сама по себе недостатонна, чтобы опреде лить среди других причину гетерогенности затухания трипмофановой флюоресценции в белках.

\section{REFERENCE}

1. Callis $P$. $R$. Origins of nonexponential tryptophan fluorescence decay in proteins // Biophys. J.- 1999. -76.-P. A2.

2. Ladokhin $A, S$. Fluorescence spectroscopy in peptide and protein analysis // Peptides and Proteins / Ed. R. A. Meyers.-Chichester: John Wiley \& Sons, Ltd., 2000.-P. $5762-5779$.

3. Lakowicz J. $R$. On spectral relaxation in proteins // Photochem. and Photobiol. -2000 . -72.-P. 421-437.

4. Szabo A. G., Rayner D. $M$. Fluorescence decay of tryptophan conformers in aqueous solution // J. Amer. Chem. Soc.1980.-102.-P. 554-563.

5. Petrich J. W., Chang M. C., McDonald D. B., Fleming G. $R$. On the origin of nonexponential fluorescence decay in tryptophan and its derivatives // J. Amer. Chem. Soc.-1983.105.-P. 3824-3832.

6. Laws W. R., Ross J. B., Wyssbrad H. R., Beechem J. M., 
Brand $L$, Sutherland J. C. Time- resolved fluorescence and ${ }^{1} H$ NMR studies of tyrosine and tyrosine analogues: Correlation of NMR-determined rotamer populations and fluorescence kinetics // Biochemistry. $-1986 .-25 .-P$. 599-607.

7. Knutson J. R., Beechem J. M., Brand L. Simultaneous analysis of multiple fluorescence decay curves: $A$ global approach // Chem. Phys. Lett. -1983.-102._P. 501-507.

8. Beechem J. M., Ameloot $M$., Brand $L$. Global and target analysis of complex decay phenomena // Anal. Instr.-1985.14.-P. 379-402.

9. Beechem J. M., Ameloot M., Brand L. Global analysis of fluorescence decay surfaces: Excited-state reactions $/ /$ Chem. Phys. Lett.-1985.-120.-P. 466-472.

10. Gryczynski J., Wiczk W., Johnson M. L., Lakowicz J. R. Lifetime distributions and anisotropy decays of indole fluorescence in cyclohexane/ethanol mixtures by frequency-domain fluorometry // Biophys. Chem. -1988.-32.-P. 173-185.
11. Ladokhin $A$. S. Red-edge excitation study of nonexponential fluorescence decay of indole in solution and in a protein // $\mathrm{J}$. Fluorescence.-1999.-9.-P. 1-9.

12. Toptygin $D$., Brand $L$. Spectrally and time-resolved fluorescence emission of indole during solvent relaxation: A quantitative model // Chem. Phys. Lett. $-2000 .-322$. -P. 496-502.

13. Nemkovich N. A., Rubinov A. N., Tomin V. L. Inhomogeneous broadening of electronic spectra of dye molecules in solutions // Principles / Ed. J. R. Lakowicz. - New York: Plenum press, 1991.-P. 367-428.

14. Toptygin D., Savtchenko R. S., Meadow N. D., Brand L. Homogeneous spectrally and time-resolved fluorescence emission from single-tryptophan mutants of IIA ${ }^{\mathrm{GlC}}$ protein $/ / \mathrm{J}$. Phys. Chem. B. -2001.-105.-P. 2043-2055.

УдК $577.32+577.322$

Надійшла до редакції 12.02.2001 